\title{
KINEMATIC ANALYSIS OF CONICAL ROTARY SUBSOIL LOOSENER FOR TILLAGE
}

\author{
Ilshat Mukhametshin ${ }^{1}$, Ayrat Valiev $^{1}$, Farzutdin Muhamadyarov ${ }^{2}$, Marat Kalimullin ${ }^{1}$, Fanis Yarullin ${ }^{1}$ \\ ${ }^{1}$ Kazan State Agrarian University, Russia; ${ }^{2}$ Vyatka State Agricultural Academy, Russia \\ ilshat858@gmail.com
}

\begin{abstract}
One of the necessary conditions for the creation of effective working bodies that ensure high quality tillage with the lowest possible energy intensity of the process is the search for the optimal geometric and kinematic parameters of the working body of the tillage implement. This problem is successfully solved for working bodies making a simple flat movement. At the same time, a significant proportion of the working bodies of agricultural machines have relatively complex working bodies, which, along with the portable rectilinear movement, rotate around its axis. So, many rotary working bodies rotate around disjoint axes and move progressively in a direction that does not coincide and does not intersect with the instantaneous axis of rotation. One of the promising designs of the working bodies for deep loosening of the soil is a rotary working body conical shape. In the article, the equations of motion of an arbitrary point of the working surface of a subsoiler of a conical shape are obtained. The subsoiler is a screw cone mounted on a bearing, with the possibility of frictional rotational movement. The main research results are obtained on the basis of theoretical study using methods of mechanics, analytical geometry and laws of agricultural mechanics. The rational parameters of the angle at the apex of the cone $\psi$ and the rear cutting angle $\varepsilon$ are revealed. Using the obtained equations, it is possible to determine the speed of action on the soil, as well as the acceleration of various points of the working surface of the cone-shaped rotary working bodies, which can be further used to analyze the process of interaction of the tool with the soil and justify its structural and technological parameters.
\end{abstract}

Keywords: tillage, equation of motion of an arbitrary point, rotational, working body, subsoil loosener.

\section{Introduction}

The determination of the optimal parameters of tillage working bodies is based on the study of the processes of their interaction with the soil [1-6] and geometric and kinematic parameters of the working bodies. Knowledge of the laws on the working bodies and their elements allows to fully set the indicators that determine the process of moving the guide elements in the soil, which makes it possible to reasonably approach the design of the subsoiler, as well as the choice of the mode of its operation [7-8].

Studies devoted to the determination of the kinematic parameters of the rotary working bodies, the implementation of complex movements in all directions, are often distributed horizontally and in the directions of movement, as of today, are frequent and describe the trajectory of the external points of the cutting element of the rotary working body [9-11].

However, in particular, for a subsoiler made in the form of a cone [12; 13], there are no equations of motion for the visible point of its working surface. The conclusions of such equations will fully interact with the soil [14-21].

\section{Materials and methods}

Overall view of the screw conical rotary subsoil loosener is shown in Fig. 1. The tool is designed to perform subsoil loosening of the soil and is a screw cone subsoiler mounted on a rack by means of bearings and ability to rotate from the reaction of the soil around its own axis [22].

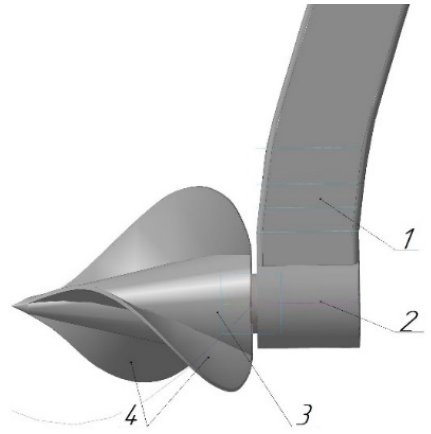

Fig. 1. Overall view of the screw conical rotary subsoil loosener:

1 - tine, 2 - bearing unit; 3 - cone, 4 - screw wings 
The main design parameters of the working body are: the radius of the base of the cone $(R=0.07 \mathrm{~m})$, the height of the cone $(H=0.15 \mathrm{~m})$, the rear cutting angle $\left(\varepsilon=5^{\circ}\right)$, the number of screw turns $(n=0.33)$.

During the movement of the tillage machine, the subsoiler is penetrated into the soil and loosens the sub-arable horizon of the soil with the formation of moles channels in it. The subsoiler can freely rotate around its axis, this ensures sliding cutting of the soil and facilitates a reduction in draft resistance, compared to a passive subsoiler, as well as a better loosening of the under-plough horizon and destruction of the hardpans.

The main research results are obtained on the basis of theoretical study using methods of mechanics, analytical geometry and laws of agricultural mechanics.

\section{Results and discussion}

The kinematic parameters of the subsoiler, which largely determine the quality and energy intensity of the soil cultivation, include the magnitude and direction of the absolute speed of movement of points on the surface of the subsoiler.

To derive the equation of motion of an arbitrary point of a subsoiler of a conical shape, we consider it in the coordinate system $O X Y Z$ Fig. 2.

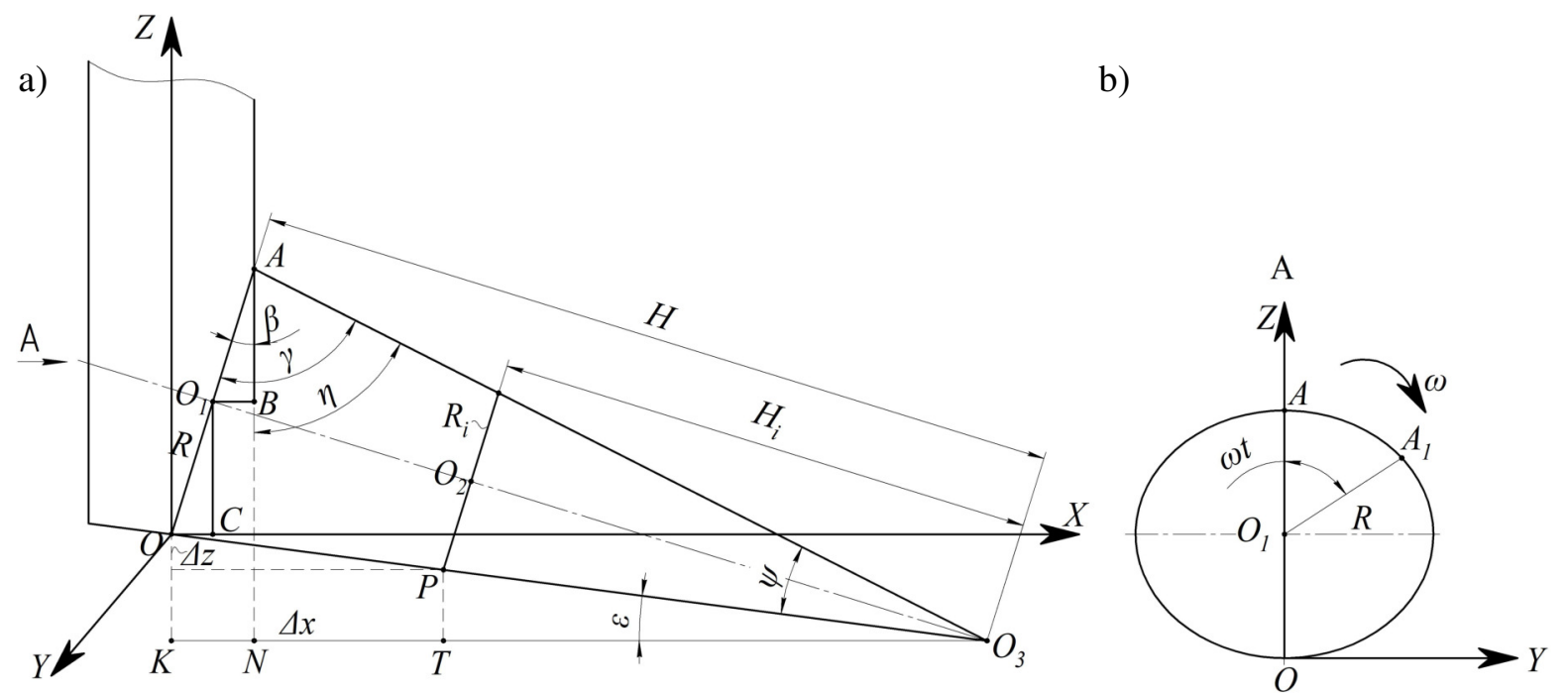

Fig. 2. Scheme of movement of the conical working body: side view (2A), view A (2b)

The radius of the base of the cone is $R=0,5 O A$. The angle at the vertex of the cone is $\psi$. Suppose that in relative motion the working body rotates at a constant frequency $\omega$, and the portable uniform movement of the working body with speed $v_{e}$ occurs along the $X$ axis. It is necessary to describe the pattern of motion of an arbitrary point on the circumference of the base of the cone in a fixed rectangular coordinate system $O X Y Z$. We introduce the following notation: $R i$ is the distance from the axis of rotation to the considered point of the cone surface; $\omega t$ - is the angle determining the position of point $A_{1}$ on the surface of the cone at time $t$. For the beginning of the report of the current rotation angle of the radius vector, we take point $A$.

At time $t$, point $A$, rotating around the axis $O_{1} O_{3}$, moves to point $A_{1}$ and rotates through an angle $\varphi=\omega \cdot t$.

At the same time, in a figurative motion in a fixed coordinate system, the point $A$ passes the distance $v_{e} t$.

The equations of motion of the point $A$ of the surface of the cone-shaped cultivator in the adopted coordinate system $O X Y Z$ at an arbitrary moment of time can be derived as a special case from the general equations of motion of an arbitrary point of motion of rotary organs (1), deduced by Professor Makarov P.I. [8]: 


$$
\left\{\begin{array}{l}
X=V_{e} \cdot t \pm R_{i}\left[\cos \alpha \sin \theta \mp\left(\frac{R}{R_{i}}+\cos \theta\right) \cdot \sin \alpha \sin \beta\right]-y_{i} \cdot \sin \alpha \cos \beta \\
Y=\mp R_{i}\left[\sin \alpha \sin \theta \pm\left(\frac{R}{R_{i}}+\cos \theta\right) \cdot \cos \alpha \sin \beta\right]-y_{i} \cdot \cos \alpha \cos \beta \\
Z=R_{i} \cdot \cos \beta \cdot\left(\frac{R}{R_{i}}+\cos \theta\right)-y_{i} \cdot \sin \beta
\end{array}\right.
$$

where the upper sign refers to the case when the working body rotates from top to bottom, and the bottom - from bottom to top;

$\alpha$ - angle of attack (degrees);

$\beta$ - angle of inclination of the working body in the vertical (degrees);

$R i$ - distance from the axis of rotation to the considered point $A(\mathrm{~m})$;

$V_{e}$ - portable speed $\left(\mathrm{m} \cdot \mathrm{s}^{-1}\right)$;

$t$ - time instant (s),

$y_{i}$ - distance from the plane of rotation of the point in question to the origin (m).

For our cone subsoiler with a height $H$, a radius of the base $R$, with an angle at the apex of the cone $\psi$ and a rear cutting angle $\varepsilon$, in the adopted coordinate system, the individual design parameters and technological adjustments will have the following values: $\theta=\varphi ; \alpha=90^{\circ} ; R_{i}=R$.

Determine the angle of inclination $\beta$ of the base of the cone to the vertical. Angle $\beta$ represents the difference in angles $\gamma$ and $\eta$. From an isosceles triangle $O_{3} A O: \gamma=\left(180^{\circ}-\psi\right) / 2$. From a triangle $O_{3} A N$ : $\eta=180^{\circ}-90^{\circ}-(\varepsilon+\varphi)=90^{\circ}-(\varepsilon+\varphi)$. Thus, the angle of inclination of the base of the cone to the vertical is:

$$
\beta=\gamma-\eta=\frac{180-\psi}{2}-90^{\circ}+\varepsilon+\psi=\varepsilon+\frac{\psi}{2} ;
$$

Substituting the value $\beta$ into equations (1), we obtain the equations of motion of point $A$ of the working surface of the cone-shaped cultivator in the adopted coordinate system:

$$
\left\{\begin{array}{l}
x=v_{e} \cdot t \mp R(1+\cos \varphi) \cdot \sin \left(\varepsilon+\frac{\psi}{2}\right) \\
y=\mp R \cdot \sin \varphi \\
z=R \cdot \cos \left(\varepsilon+\frac{\psi}{2}\right)(1+\cos \varphi) .
\end{array}\right.
$$

In equation (3), the upper sign refers to the case when the cone-shaped organ rotates counterclockwise, and the lower sign refers to its clockwise rotation.

This system of equations determines the position of any point on the surface of the base of the cone-shaped subsoiler.

In order to find the coordinates of a similar point on the surface of the cone-shaped ripper at $R=R_{i}$, it is necessary to find the magnitude of the change in the $X$ and $Z$ coordinates, i.e. $\Delta X$ and $\Delta Z$.

Consider $\triangle \mathrm{OO}_{1} \mathrm{O}_{3}$ :

$$
\frac{O_{1} O_{3}}{O O_{3}}=\cos \frac{\psi}{2} \text {; from here } O O_{3}=\frac{H}{\cos (\psi / 2)} .
$$

From $\triangle \mathrm{OKO}_{3}$ :

$$
\frac{O K}{O O_{3}}=\sin \mathcal{\varepsilon}, O K=O O_{3} \sin \varepsilon=\frac{H \cdot \sin \varepsilon}{\cos (\psi / 2)} .
$$

Similarly, for another section of the cone, we find

$$
P T=\frac{H_{i} \cdot \sin \varepsilon}{\cos (\psi / 2)} .
$$


Therefore, the change in the $Z$ coordinate upon transition to the radius $R_{i}$ is:

$$
\Delta Z=O K-P T=\frac{H \cdot \sin \varepsilon}{\cos (\psi / 2)}-\frac{H_{i} \cdot \sin \varepsilon}{\cos (\psi / 2)}=\frac{(H-H i) \sin \varepsilon}{\cos (\psi / 2)} .
$$

From $\triangle P \mathrm{O}_{2} \mathrm{O}_{3}$ :

$$
H_{i}=\frac{R_{i}}{\operatorname{tg}(\psi / 2)} .
$$

Change of $X$ coordinate upon transition to radius $R_{i}$

$$
\begin{gathered}
\Delta X=K T=\left(O_{3} O-O_{3} P\right) \cdot \cos \varepsilon, \\
O_{3} P=\frac{H_{i}}{\cos (\psi / 2)} ; \\
\Delta X=K T=\left(\frac{H}{\cos (\psi / 2)}-\frac{H_{i}}{\cos (\psi / 2)}\right) \cos \varepsilon=\frac{\left(H-H_{i}\right) \cos \varepsilon}{\cos (\psi / 2)} .
\end{gathered}
$$

Therefore, the coordinates of any point on the surface of the of the subsoiler in the adopted Cartesian coordinate system, taking into account formulas (3), (4), (7), are described by the system of equations:

$$
\left\{\begin{array}{l}
x=v_{e} \cdot t \mp R_{i}(1+\cos \varphi) \cdot \sin (\varepsilon+\psi / 2)+\frac{\left(H-H_{i}\right) \cos \varepsilon}{\cos (\psi / 2)} \\
y=\mp R_{i} \cdot \sin \varphi \\
z=R_{i} \cdot \cos \mathcal{E}(1+\cos \varphi)-\frac{\sin \varepsilon\left(H-H_{i}\right)}{\cos (\psi / 2)} .
\end{array}\right.
$$

where $\varepsilon+\psi / 2=\varepsilon_{i}$.

We study the equations of motion of the point of the screw of the subsoiler. To do this, by setting the parameters $\varepsilon, \psi$, and $\varphi$ to different values, we compare the resulting equations with the known equations of motion of the points of various tillage machines.

From expressions (3) and (8) at $\varepsilon=0$ (which is typical for the knives of tillage machines performing thinning seedlings), the system of equations (8) takes the following form:

$$
\left\{\begin{array}{l}
x=v_{e} \cdot t+\frac{\left(H-H_{i}\right) \cos \varepsilon}{\cos (\psi / 2)} \\
y= \pm R_{i} \cdot \sin \varphi \\
z=R_{i} \cdot(1+\cos \varphi)
\end{array}\right.
$$

which corresponds to the equations of motion of an arbitrary point of a knife of rotary tillage machines. When $\varepsilon_{i=} 0$ and $\psi=0$ (i.e., $R_{i=} 0$ ), the working body turns into a flat knife, the equation of motion of which along the $O X$ axis has the form:

$$
x=v_{e} \cdot t .
$$

When $\varphi=\omega t=0$, we obtain the equations of motion of the points of the upper guide of the working surface of the passive conical scavenger, which have the following form:

$$
\left\{\begin{array}{l}
x=v_{e} \cdot t+2 R_{i} \cdot \sin (\varepsilon+\psi / 2)+\frac{\left(H-H_{i}\right) \cos \varepsilon}{\cos (\psi / 2)} \\
y=0 \\
z=2 R_{i} \cdot \cos \varepsilon-\frac{\sin \varepsilon\left(H-H_{i}\right)}{\cos (\psi / 2)}
\end{array}\right.
$$


Thus, using the obtained equations, we determine the rate of action on the soil of various points of the working surface of the conical subsoiler.

The projections of the velocity of the points of the working surface of the conical working body on the coordinate axis are defined as the first time derivatives from the derived equations (8):

$$
\left\{\begin{array}{l}
V_{x}=v_{e} \pm v_{0} \cdot \sin \omega t \cdot \sin \left(\varepsilon+\frac{\psi}{2}\right) \\
V_{y}=v_{0} \cdot \cos \omega t=\omega R \cdot \cos \omega t \\
V_{z}=-v_{0} \cdot \cos \varepsilon_{i} \cdot \sin \omega t
\end{array}\right.
$$

The absolute velocity module of the impact of a point of the subsoiler on the soil is defined as:

$$
V_{i}=\sqrt{v_{x}^{2}+v_{y}^{2}+v_{z}^{2}} .
$$

The issues of analytical research of the laws of motion of rotating bodies have been studied by many authors such as Zheligovsky V. A., Destain M.-F., Gainanov H. S., Makarov P. I., Valiev A. R., Bulgariev G. G., [14-21]. However, the equations of motion of working bodies of agricultural and other machines obtained by them are only a special case of the general equation under consideration and do not allow determining the coordinates of any point of the tool at any time.

The equations obtained by us allow to determine the characteristics of movement and interaction with the tillage soil of an arbitrary point on the surface of a screw rotary subsoiler, taking into account the design features.

Based on the calculation results, the projections of the velocity $V$ of the point of the working surface of the developed subsoiler on the coordinate axis $O X$ were obtained, a graphical interpretation of which is presented in Fig. 3.
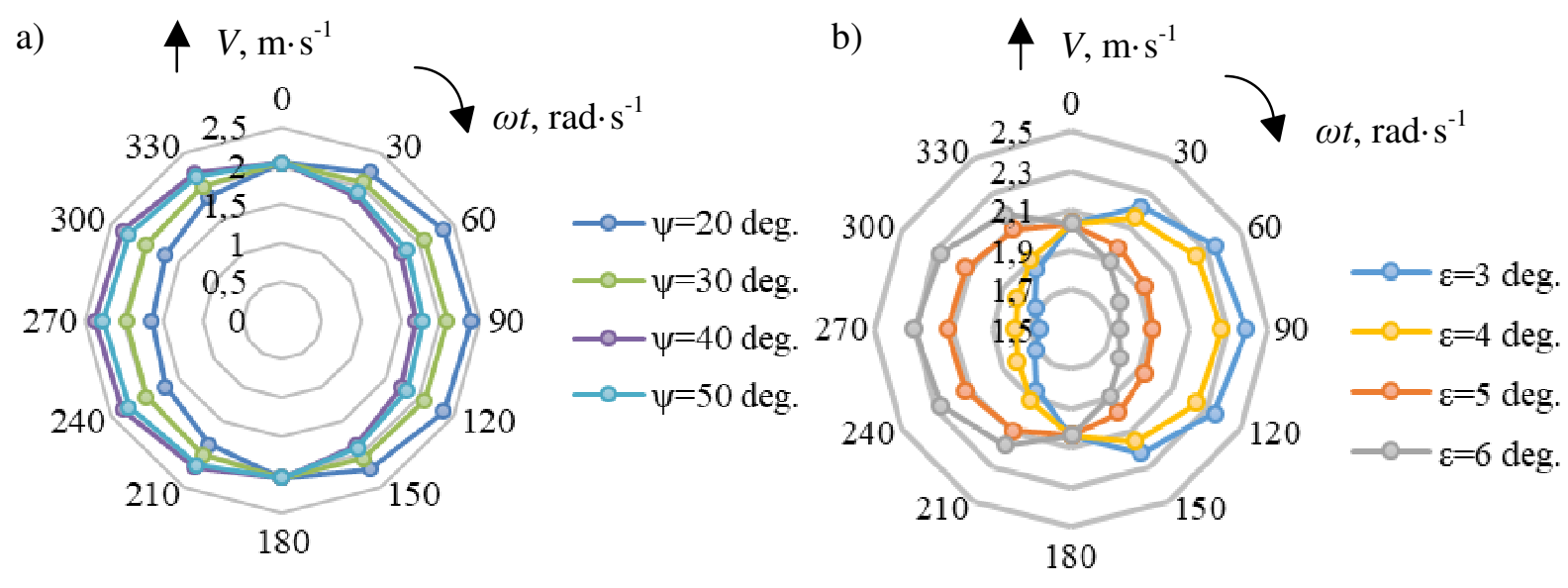

\section{Fig. 3. Dependence of the projection of the velocity of the point of the working surface of the cultivator on the coordinate axis $O X$ on the angle of rotation at different angles at the apex of the cone $\psi(a)$ and the values of the rear cutting angle $\varepsilon(b)$}

As it can be seen from Fig. $3 a$, the change in the angle when exposed to the top is independent of speed, but at a speed of rotation $\psi=30^{\circ}$. This will stabilize the rotation of the rotary subsoiler. When changing the rear cutting angle, Fig. $3 b$, the most effective impact of the working surface on the soil is observed at $\varepsilon=5^{\circ}$, decrease in the angle of incidence of the operating point.

\section{Conclusion}

The article presents the obtained equations for determining the speed, as well as accelerating the impact on the soil of various points of the working surface of the conical subsoiler. 
As it can be seen from equations (12), (13) and Figure 3, the modulus of the velocity of the impact of a point of the working surface on the soil depends on the values of the speed of its translational and rotational motion, the cutting back angle, and on the location of the considered point of the subsoiler with the soil.

The equations obtained by us allow to more fully reflect the character of the interaction of the conical rotary subsoiler with the soil, taking into account the design characteristics.

\section{References}

[1] Горячкин В. П. Собрание сочинений. В 3 т. (Collected works. In 3 t.) - 2-е изд. - М.: Колос, 1968. - T. 1. - 1968. - 720 c. (In Russian).

[2] CIGR Handbook of Agricultural Engineering. Ed. Bill A. Stout. Texas A\&M University. Published by ASAE, 1999. - $660 \mathrm{p}$.

[3] Mudarisov S.G., Gabitov I.I., Lobachevsky Y.P., Mazi tov N.K., Rakhimov R.S., Khamaletdinov R.R., Rakhimov I.R., Far khut dinov I.M., Mukhametdinov A.M., Gareev R.T. Modeling the technological process of tillage. Soil \& Tillage Research. 2019. Vol. 190. pp. 70-77.

[4] Florian Schneider, Axel Don, Inga Hennings, Oliver Schmittmann, Sabine J. Seidel The effect of deep tillage on crop yield - What do we really know? Soil \& Tillage Research. 2017. Vol. 174. pp. 193-204.

[5] Deep diggers give a high lift to yields // Farmers Weekly. - 1991. - Vol. 115, № 18. 42 p.

[6] Borowski P., Klimkiewicz M., Powałka M. Selected problems of soil tillage systems and operations. Warsaw: WEMA. Warsaw University of Life Sciences, 2010. 133 p.

[7] Мударисов С.Г., Рахимов 3.С., Фархутдинов И.М. Реализация математической модели процесса взаимодействия рабочих органов с почвой при работе на склонах (Implementation of a mathematical model of the process of interaction of working bodies with the soil when working on slopes) // Фундам. основы научно-технич. и технологич. модернизации АПК: материалы Всеросс. науч.-практ. конф. - Уфа: Изд-во Башкирского ГАУ, 2013. - С. 205213. (In Russian).

[8] Макаров П.И. Научные основы технологии и ротационных машин для гладкой обработки почвы (Scientific basis of technology and rotary machines for smooth tillage), автореф. дисс. ... д-ра техн. наук: 05.20.01. - Москва, 2000. - 48 с. (In Russian).

[9] Мазяров В.П. Подпокровный рыхлитель значительно снижает энергозатраты при почвообработке (Soil subsoiler Ripper significantly reduces the energy consumption during the tillage) [Электронный ресурс]/В.П. Мазяров, В.И. Медведев. 2013. - [onlin][11.02.2020] Available at: http://www.polytech21.ru/news/1846-podpokrovnyj-rykhlitel-znachitelno-snizhaetenergozatraty-pri-pochvoobrabotke, вход свободный. (In Russian).

[10]Гайнанов Х.С., Макаров П.И. Об уравнениях движения ротационных органов почвообрабатывающих машин (About equations of motion of rotary bodies of tillage machines) // Труды ЧИМЭСХ. Вып. 167. - Челябинск, 1981. - pp. 95-98. (In Russian).

[11]Fouda O.A. A Spiral Rotor Tiller for Tillage Heavy and Dry Clay Soil/Fouda, O.A. // J. Soil Sci. and Agric. Eng., Mansoura Univ., Vol. 7 (12), 2016. - pp. 929-936.

[12] Мухаметшин И. С., Макаров П. И., Валиев А. Р. Патент РФ на изобретение 2553380, МПК7 A01B 79/00, 3/28. Способ противоэрозионной обработки почвы на склонах и устройство для его осуществления (Method of anti- erosion tillage on slopes and device for its implementation) Claimed 20.11.2013; published 10.03.2015, Bulletin No 16, 10 p. (In Russian).

[13] Valiev A., Mukhametshin I., Muhamadyarov F., Yarullin F., Pikmullin G. 18-th International Scientific Conference Engineering for Rural Development Proceedings. Latvia University of Agriculture. Faculty of Engineering. 18, 2019, pp. 312-318.

[14]Желиговский, В.А. Элементы теории почвообрабатывающих машин и механической технологии с.-х. материалов (Elements of the theory of tillage machines and mechanical technology of agricultural materials)/ В.А. Желиговский// - Тбилиси: Изд. Грузинского СХИ , 1960. - 146 c. (In Russian).

[15] Destain M.-F., Houmy K.. Effects of design and kinematic parameters of rotary cultivators on soil structure. Soil \& Tillage Research. 1990. Vol. 17, Issues 3-4, pp. 291-301. 
[16]Гайнанов Х.С., Макаров П.И. Об уравнениях движения ротационных органов почвообрабатывающих машин (About equations of motion of rotary bodies of tillage machines) // Труды ЧИМЭСХ. Вып. 167. - Челябинск, 1981. - С. 95-98. (In Russian).

[17]Матяшин Ю.И. Ротационные почвообрабатывающие машины (теория, расчет и эксплуатация) (Rotary tillage machines (theory, calculation and operation)/Ю.И. Матяшин, Н.Ю. Матяшин//. - Казань: Издательство Казанского ГАУ, 2008. - 204 с. (In Russian).

[18]Валиев А.Р. Исследование процесса движения почвы по рабочей поверхности дискового культиватора (Investigation of the process of soil movement on the working surface of a disk cultivator ). Вестник Казанского ГАУ. - 2017. - № 3. - pp. 54-60. (In Russian).

[19] Юнусов Р.Г., Булгариев Г.Г., Пикмуллин Г.В. Уравнения движения ротационных (винтовых) рабочих органов в почве (Equations of motion of rotary (screw) working bodies in the soil). Вестник Казанского государственного аграрного университета. Вестник Казанского ГАУ., 2012. - № 4. - pp. 88-90. (In Russian).

[20] Ahmadi I. A power estimator for an integrated active-passive tillage machine using the laws of classical mechanics/I. Ahmadi // Soil \& Tillage Research, 171, 2017. - pp. 1-8.

[21]Путрин А.С., Избасарова 3.И., Слободяник В.А., Коняхин П.П., Классен Ю.П. Теоретические основы движения элементарных участков исполнительных поверхностей ротационных почвообрабатывающих рабочих органов (The theoretical basis of the movement of the elementary parts of the Executive surfaces of the rotational soil-cultivating working bodies)// Известия Оренбургского ГАУ. - 2012. - № 1 (33). pp. 77-81. (In Russian).

[22] Mukhametshin I.S., Valiev A.R., Aleshkin A.V., Ibyatov R.I., Mukhamadyarov F.F. Study of the influence of the oncoming flow of soil on the screw surface of a subsoiler/International ScientificPractical Conference "Agriculture and Food Security: Technology, Innovation, Markets, Human Resources” (FIES 2019). BIO Web Conf. 17, 00118 (2020). DOI: 10.1051/bioconf/20201700118. 